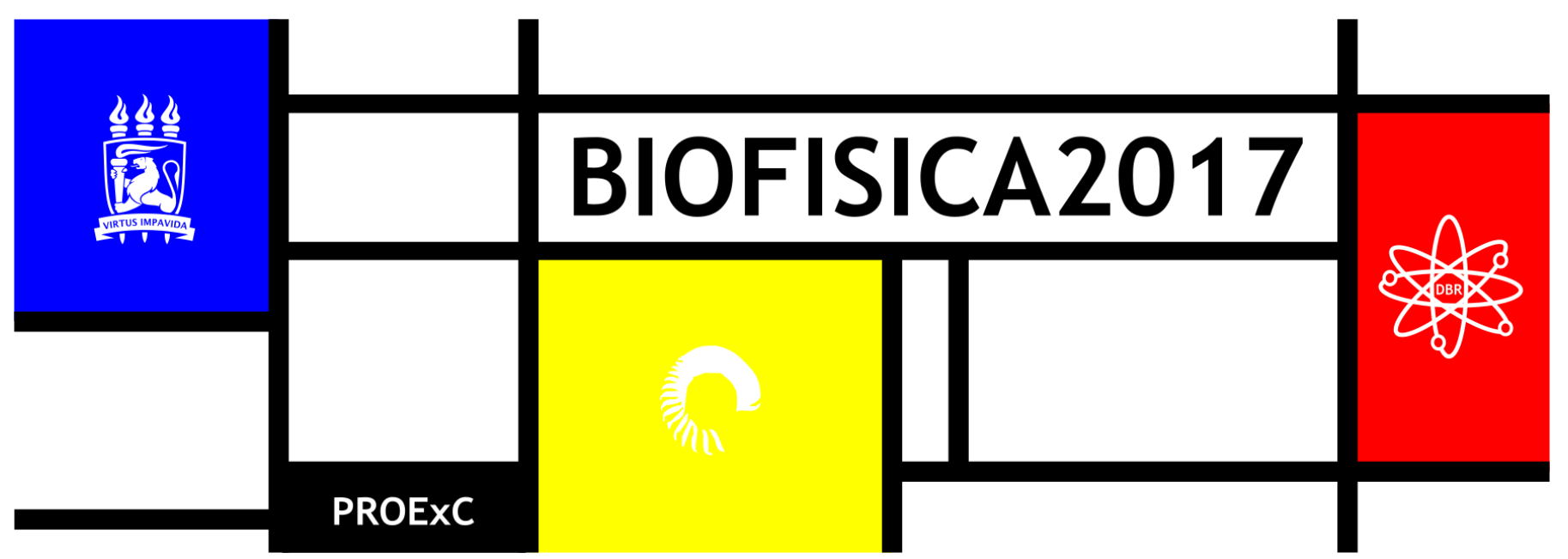

\title{
ALFABETIZAÇÃO CIENTÍFICA: INTERFACES ENTRE TEORIA E PRÁTICA SOBRE O ENSINO DE GENÉTICA NA EDUCAÇÃO BÁSICA
}

\author{
Eduarda Santos de Santana ${ }^{1}$, Elivelton Veríssimo de Souza², Suzane Bezerra de França ${ }^{3}$. \\ Laboratório de Biofísica Química ${ }^{1}$, Laboratório de Processos Biotecnológicos ${ }^{2}$, Centro de Educação - UFPE ${ }^{3}$ \\ *eduardabio14@gmail.com
}

\section{INTRODUÇÃO}

O ensino de genética básica visa interligar os conceitos de transmissão de atributos hereditários no decorrer das gerações com as estruturas dos elementos que as formam (cromossomo, DNA, RNA). O DNA é a unidade básica para estudos em genética, é nele que serão transpassadas as informações contidas de seus ancestrais que servirão para a manutenção da vida dos seres vivos, já o RNA, por sua vez, é gerado a partir de uma cópia da molécula de DNA, mas este último está diretamente ligado à produção de proteínas nos organismos. As principais diferenças entre essas duas moléculas (DNA e RNA) está nas suas formas estruturais. O DNA possui quatro bases nitrogenadas, são elas: Adenina, Timina, Guanina e Citosina, sua pentose, ou seja, o açúcar, constituinte é a desoxirribose, e contém também um grupamento de fósforo; enquanto no RNA, possui quatro bases nitrogenadas: Adenina, Uracila, Guanina e Citosina, como açúcar contém a ribose, e assim como o DNA, também adere a um grupamento fosfato, diferenciado apenas pela posição da hidroxila $(\mathrm{OH})$. Diversas doenças humanas são hereditárias. 0 estudo do genótipo de um casal e seus parentes permite estimar a chance de uma criança ser afetada por uma doença já manifestada em alguns membros da família (AMABIS et al., 2010). Essas doenças estão ligadas diretamente na deficiência, ausência ou excesso, de cromossomos existentes no indivíduo. As doenças genéticas atingem a sequência de nucleotídeos (unidades formadoras de DNA), todas são incuráveis. 0 que temos atualmente são apenas técnicas que retardam o avanço da doença e reduzem os sintomas, melhorando a qualidade de vida. (SANTOS, 2014). Através de conteúdo específicos, como o da genética, percebemos a importância de sua introdução em sala de aula e com isso compreendemos que: o ensino por investigação toma por inspiração a construção do conhecimento em processos de pesquisa científica e se fundamenta na orientação fornecida pelo professor; privilegia práticas da comunidade científica e propõe explicações baseadas em evidências do trabalho investigativo (GUISASOLA et al., 2007; SMITHENRY, 2010). Os assuntos abordados no ensino de ciências nas escolas da Educação Básica têm como método, na maioria das vezes, ser apresentado apenas a parte teórica dos assuntos, deixando assim os alunos com dúvidas ou conceito equivocados dos temas abordados em sala de aula. As atividades práticas e o ensino por investigação têm seu foco deslocado da aquisição de conteúdos teóricos para o desenvolvimento de habilidades que são próximas do "fazer científico". É importante que, além dos aspectos relacionados aos procedimentos como observação, manipulação de materiais de laboratório e experimentação, as atividades práticas e investigativas incluam a motivação e o estímulo para refletir, discutir, explicar e relatar, o que promoverá as características de uma investigação científica. Alguns aspectos da natureza da Ciência são universais e, na opinião de Abd-El-Khalick e colaboradores (1998), devem ser abordados pela educação científica da escola básica de forma a desenvolver familiaridade com as práticas científicas e com a maneira de essa área articular a sua construção do conhecimento (DRIVER et al., 2000). São motivações como essas que levam professores, educadores e pesquisadores a buscarem e valorizarem atividades práticas, investigativas e experimentais. De diferentes formas, cada um desses tipos de atividades pode ter uma contribuição própria no esforço pela aproximação dos estudantes com a cultura científica, pela familiaridade com as práticas da ciência e com suas formas de construir conhecimento. (TRIVELATO, 2015). Sendo assim, o objetivo deste trabalho é analisar uma sequência didática na perspectiva de uma alfabetização científica, envolvendo conceitos de genética na Educação Básica. A intervenção didática envolveu através a extração de DNA trabalhamos a compreensão do "fazer científico" nos conceitos básicos da genética, além de analisar a composição do DNA compreendendo as doenças genéticas, acrescentando no conhecimento desses alunos não só os conceitos teóricos, mas a capacidade de compreender e analisar situações do cotidiano com uma perspectiva diferente.

\section{MATERIAIS E MÉTODOS}

0 presente trabalho foi realizado com estudantes do ensino fundamental (séries finais), a partir do $9^{\circ}$ ano da Escola Professor José Vicente Barbosa, localizada na Praça Aleixo de Oliveira - S/N, bairro do IPSEP, Recife-PE. O desenvolvimento, da sequência didática ocorreu em quatro aulas com duração de 50 minutos cada. A princípio foi realizada um conjunto de observações na referida escola, como parte das atividades proposta no Estágio em Ensino de Biologia 1, que entre outros aspectos visou verificar a 
disponibilidade de recursos, bem como conhecimento sobre a dinâmica de sala de aula. No primeiro momento, foram realizadas aulas teóricas com o auxílio de um resumo escrito no quadro sobre introdução à genética em que foram abordados os princípios de sua evolução, relatos históricos, relação com patogenicidades, funções estruturais e sua importância social bem como testes de paternidades e testes de hereditariedade.

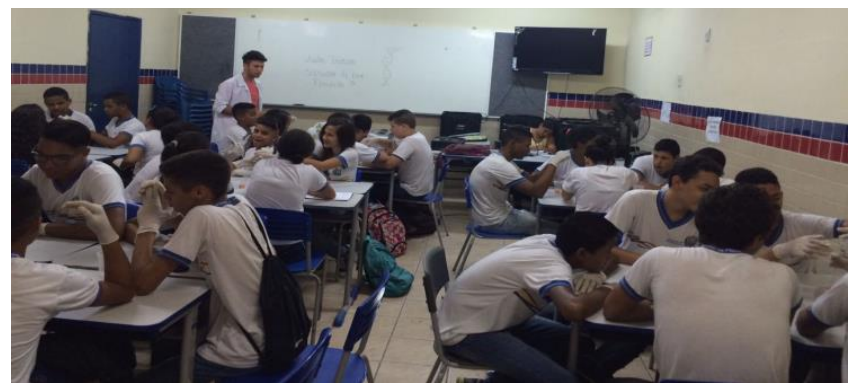

Figura 1 - Dialogo entre professor e aluno sobre os questionamentos do assunto. Fonte: 0 autor (2016).

Em seguida, no segundo momento, foram utilizadas as duas aulas subsequentes, em que foi feito o momento prático com toda a turma participando. Antes do início das aulas práticas, fizemos uma revisão do conteúdo visto nas etapas anteriores (aulas teóricas e palestras), com perguntas e situações que envolvem os assuntos da genética, fazendo os alunos relacionar com questões vistas no seu cotidiano. Na prática, os alunos fizeram a extração de DNA da pimenta biquinho e foram separados em seis grupos (Figura 2) com no máximo cinco alunos cada grupo.

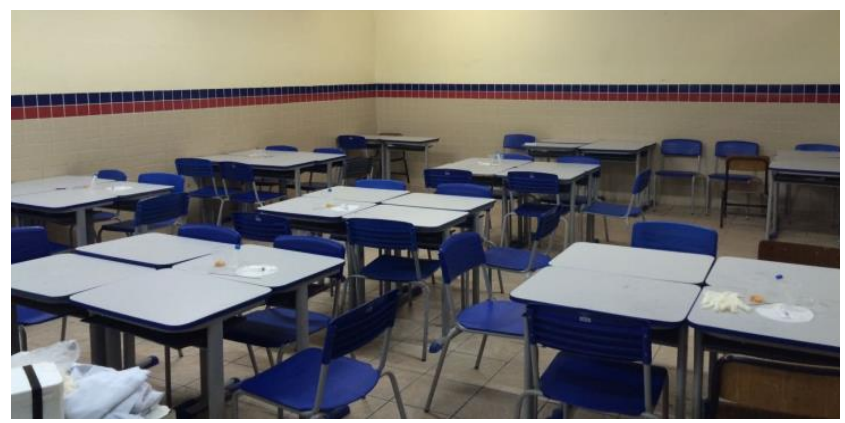

Figura 2 - Divisão das carteiras da sala em seis grupamentos. Fonte: 0 autor (2016).

Foi preparado um material específico para realização das atividades, foram eles: Um par de luvas para cada estudante, solução de lise (foi preparada uma solução de proporção 10:1 de água e detergente adicionando quatro colheres de café de sal a cada $60 \mathrm{ml}$ da mistura), tubos falcon, filtros de TNT, seringas sem agulhas de $5 \mathrm{ml}$, copos descartáveis (usado para descarte dos materiais), pimentas de cheiro do tipo biquinho, saquinhos de picolé, palito de churrasco e ácido etílico à $99,9 \%$ ou $70 \%$ (álcool convencional), este último a manipulação foi de inteira responsabilidade dos professores (Figura 3 ).

No saquinho de picolé, foram colocadas seis pimentas e $15 \mathrm{ml}$ da solução de lise e pediu-se para que eles amassassem as pimentas o máximo que conseguissem. Feito isso, a solução foi filtrada (mediante o filtro de TNT) dentro do tubo falcon, toda a mistura obtida; em seguida o professor passou com o Etanol gelado (ácido etílico $99,9 \%$ ) em cada grupo e pediu-se que adicionassem o dobro da quantidade já existente; depois aguardamos a condensação do DNA até que ficasse visível a olho nu, o palito de churrasco servira para pegar o DNA (Figuras 4 e 5 ).

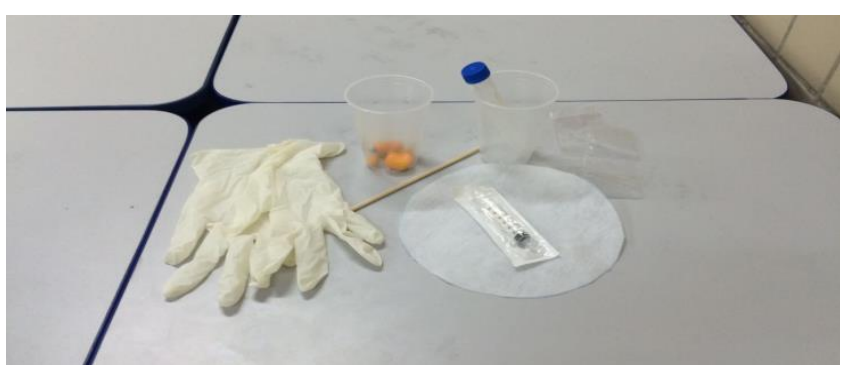

Figura 3 - Material utilizado pelos alunos. Fonte: 0 autor (2016).

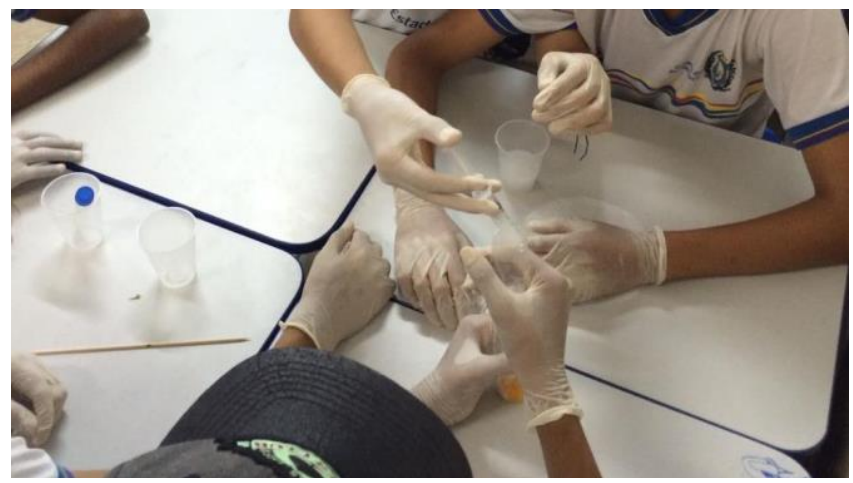

Figura 4 - introdução da solução de lise. Fonte: 0 autor (2016).

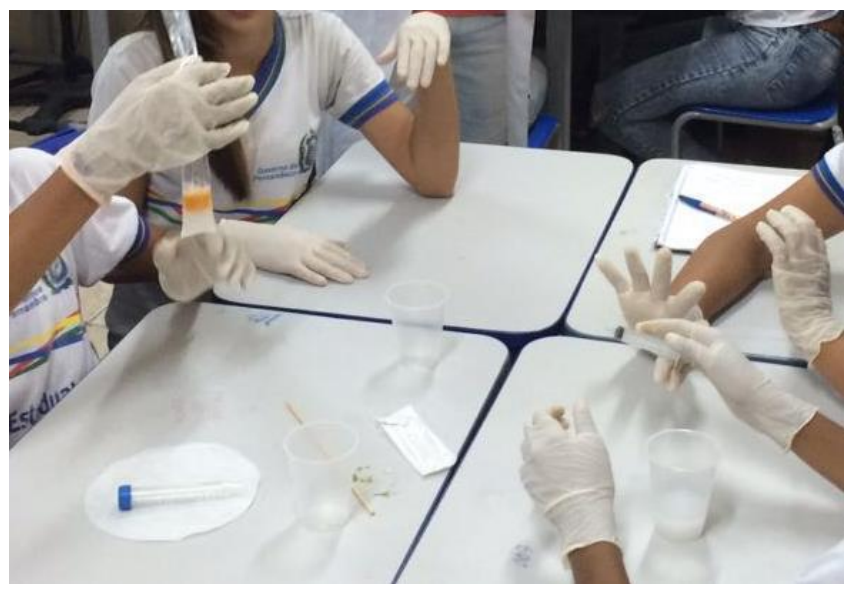

Figura 5 - Homogeneização da amostra. Fonte: 0 autor (2016).

\section{RESULTADOS E DISCUSSÃO}

Entre os objetivos de ensino, consta a intenção de evidenciar a importância do estudo da genética no ensino fundamental. A apresentação foi realizada para o $9^{\circ}$ ano do ensino fundamental ॥ de uma escola estadual em Recife. No primeiro momento, foi realizada uma roda de discussão, foram levantados pelos alunos os seguintes questionamentos:

. Para que serve a o estudo na genética?

. Onde consigo ver a genética no meu dia-a-dia?

. O que é DNA e RNA?

. Cromossomo é uma célula?

. Quais doenças estão relacionadas?

. Posso ter doenças genéticas depois de grande?

. Tem como evitar algumas doenças?

A partir das concepções dos alunos, fomos esclarecendo suas dúvidas de forma que entendessem a seus modos, aplicando, principalmente, as formas visíveis de estudos sobre as unidades básicas de genética mostrando-os o DNA condensado (apresentado 
na segunda etapa do projeto). Os dados revelados nos permitem constatar que há um déficit no conhecimento sobre o estudo de genética e o fazer científico. Para COBERN e AIKENHEAD, a alfabetização científica caracteriza-se por ser uma via da aprendizagem em aulas de Ciências em que o aprendizado se dá por meio da aquisição de uma nova cultura, no caso, a cultura científica, considerando os conhecimentos já estabelecidos na cultura cotidiana do indivíduo (COBEM E AIKENHEAD, 1998). Os alunos, por exemplo, têm uma concepção ambígua sobre a genética, não conseguindo assimilar de forma concisa seus benefícios e malefícios, principalmente no contexto social. Esses resultados também nos fizeram perceber a importância da realização de aulas práticas para os conteúdos que foram aplicados, pois através do entusiasmo dos alunos em manipular a atividade proposta, constatamos maior envolvimento na para a compreensão do tema. Sendo assim, indicado por CHASSOT que alfabetização científica pode ser considerada como uma das dimensões para potencializar alternativas que privilegiam uma educação mais comprometida (CHASSOT, 2003).

\section{CONCLUSÕES}

O desenvolvimento da sequência didática, possibilitou perceber que a escola não está devidamente preparada para inserção de aulas práticas por não possuir equipamentos que permitam os professores a trabalharem uma gama de assuntos, no que se refere a laboratórios para ensino de ciências e suas tecnologias e disponibilidade de materiais de uso lúdico-laboratorial. Quanto aos alunos, constatamos que houve maior interesse da turma em participar das aulas quando dispomos materiais práticos para que pudessem acompanhar de forma dinâmica e real, os processos da genética, que no nosso caso foi a extração do DNA, a partir de métodos e compostos que eles usam no dia-a-dia. Percebemos também que a partir dos conceitos prévios que esses estudantes já tinham sobre alguns aspectos do tema aplicado, puderam tirar suas dúvidas de forma a entender e fixar a importância e uso das técnicas genéticas na vida quando nos referimos, em especial, ao contexto socioeducativo.

As análises feitas, indicam que apesar da lacuna apresentada na educação básica, que poderia interferir na qualidade do ensino continuo de ciências, é indispensável que os educadores tenham formações incessantes e desfrutem sempre de materiais atualizados, para que criem novos métodos, que junto ao conceitual, façam com que os seus alunos possam ver em experimentações, os acontecimentos e com isso criem pensamentos críticos e pertinentes quanto ao conhecimento cientifico.

\section{REFERÊNCIAS}

ABD-EL-KHALICK, F.; BELL, R.; LEDERMAN, N. The nature of science and instrucional pratice: Making the unnatural natural. Science Education, v. 82, n. 4, p. 417-436, 1998.

AMABIS, J.M.; MARTHO, G.R. Biologia das populações. Editora Moderna LTDA. São Paulo, V.3, C.8, P.162, 2010.

CHASSOT, Attico. Alfabetização científica: uma possibilidade para a inclusão social. Rev. Bras. Educ. [online]. 2003, n.22, pp.89-100. ISSN 1413-2478. http://dx.doi.org/10.1590/S141324782003000100009.

COBERN, W.W. \& AIKENHEAD, G.S. Cultural Aspects of Learning Science. Part One. Kluwer Academic Publishers, 1998.

DRIVER, R.; NEWTON, P.; OSBORNE, J. Establishing the Norms of a Scientific Argumentation in Classrooms. Science Education, v. 84, n. 3, p. 287-312, 2000.

GUISASOLA, J. et al. Designing and Evaluating research-based instructional seqeunces for introducing magnetic fields. International Journal of Science and Mathematics Education, v. 7, n. 4, p. 699-722, 2009.
SANTOS, V. Doenças genéticas, 2014. Biologia net. Disponível em: <http://biologianet.uol.com.br/doencas/doencas-geneticas.htm> Acesso em: 16 de outubro de 2016.

SMITHENRY, D. W. Integrating Guided Inquiry into a Traditional Chemistry Curricular Framework. International Journal of Science Education, v. 32, n. 13, p. 1689-1714, 2010.

TRIVELATO, S. L. U. Ensino por investigação: eixos organizadores para sequências de ensino de biologia. Revista Ensaio. Belo Horizonte, v.17, n especial, p.97-114, nov, 2015. 